\title{
CONDITIONS AND DIRECTIONS OF INVESTING ON THE WORLD REAL ESTATE MARKET
}

\author{
Ewa Siemińska, prof. \\ Nicolaus Copernicus University in Torun \\ Faculty of Economic Sciences and Management \\ e-mail:ewahsiem@umk.pl \\ Małgorzata Krajewska, PhD \\ Nicolaus Copernicus University in Torun \\ Faculty of Economic Sciences and Management \\ e-mail: gosiak@econ.umk.pl
}

\begin{abstract}
The main topic assumed in the article are investments in the real estate market, with particular consideration given to their scale and changes in the directions of investing in the context of a dynamically changing geopolitical and economic situation throughout the world. This is seeing as how the activity of investors reflects the need and preferences of various groups of buyers and users of built surfaces, while accounting for the risk accompanying investment decisions as well as the widely understood operating conditions.

Constant observation and monitoring of these phenomena, their dynamics as well as structural changes is a remarkably important and very needed study, both as far as science and practical application are concerned, as it allows for the processes taking place to be tracked, while their informational value is more valuable the more uncertain the market and more difficult it and the behaviors of its participants are to predict.

The work uses the newest available reports and analyses of the largest auditors dealing with worldwide and global real estate markets, such as: JLL, Colliers International, CBRE, Cushman\&Wakefield, KPMG, World Economic Forum, or Savills and UBS Group Ag.

The aim of the work is the synthetic analysis of changes and directions of investing on the real estate market on a global scale, in the context of the newest political-economic situations throughout the world.
\end{abstract}

Key words: real estate market, investments, world, business cycle.

JEL Classification: F21, R30.

Citation: Siemińska E., Krajewska M., 2017, Conditions and Directions of Investing on the World Real Estate Market, Real Estate Management and Valuation, vol. 25, no. 4, pp. 99-112.

DOI: 10.1515/remav-2017-0033

\section{Introduction}

The scale and intensity of interest as well as the investment activity of various market participants is dependent on the intertwinement of various, often simultaneously occurring factors and external as well as internal determinants, dependent on or independent of the investor. The market is a system of connected vessels functioning in a given geopolitical and social environment, thus many events and decisions made in one area influence the behavior and directions of actions in other spheres of activity.

In 2016, changes of a global dimension for the economy undoubtedly took place in the multinational arena, the echoes of which will resound not only in 2017, but also in the years or even 
decades to come. The most important of these are sure to include: the decision of Great Britain to separate from the structures of the European Union (referred to as Brexit) made in the referendum that took place on 23 June 2016 and the election of Donald Trump as the $45^{\text {th }}$ President of the United States of America in November. This and other geopolitical factors throughout the entire world are causing a feeling of uncertainty which had not been encountered for a long time and difficulties in predicting the scenarios of development in many areas of not only political, but also economic and social life. This, in turn, according to experts from Cushman \& Wakefield as well as World Economic Forum, will generate an aversion to risk of many potential investors and transfer over to the level of activity on the global and national real estate markets (What Next for European Property Investment?, 2017, The Global Risks Report, 2016).

The increased dynamics of changes on the international arena, and especially the development of the globalization process, also covering the real estate market and strengthened by institutionaleconomic regulations of local national markets, results in the undertaking of different action strategies and decisions by various groups of real estate market participants (ANOP 2010; BOLEAT, COLES 2012; BROWN 2015; BREXIT 2016).

\section{Review of topic-related literature}

Studies of the directions of the development and changes taking place on the real estate market, from a global, regional as well as local perspective, especially accounting for the widely-understood conditions of this market, require research to be continuously carried out in order to better identify and deepen knowledge, not only on the grounds of economic studies, but also, e.g., behavioral ones, connected with demographics, urban planning, architecture, information-technology, transport, ecology, sociology, cultural anthropology or gerontology. The need for a comprehensive and interdisciplinary approach to studying the changes taking place on the real estate market results especially from the basic functions and significance of real estate in the life of every person, at various stages of his/her life, and in various social-economic or cultural roles. Graphically, these connections have been symbolically presented in the form of the so-called "House of Real Estate Economics," among others by K.W. Schulte (Fig. 1).

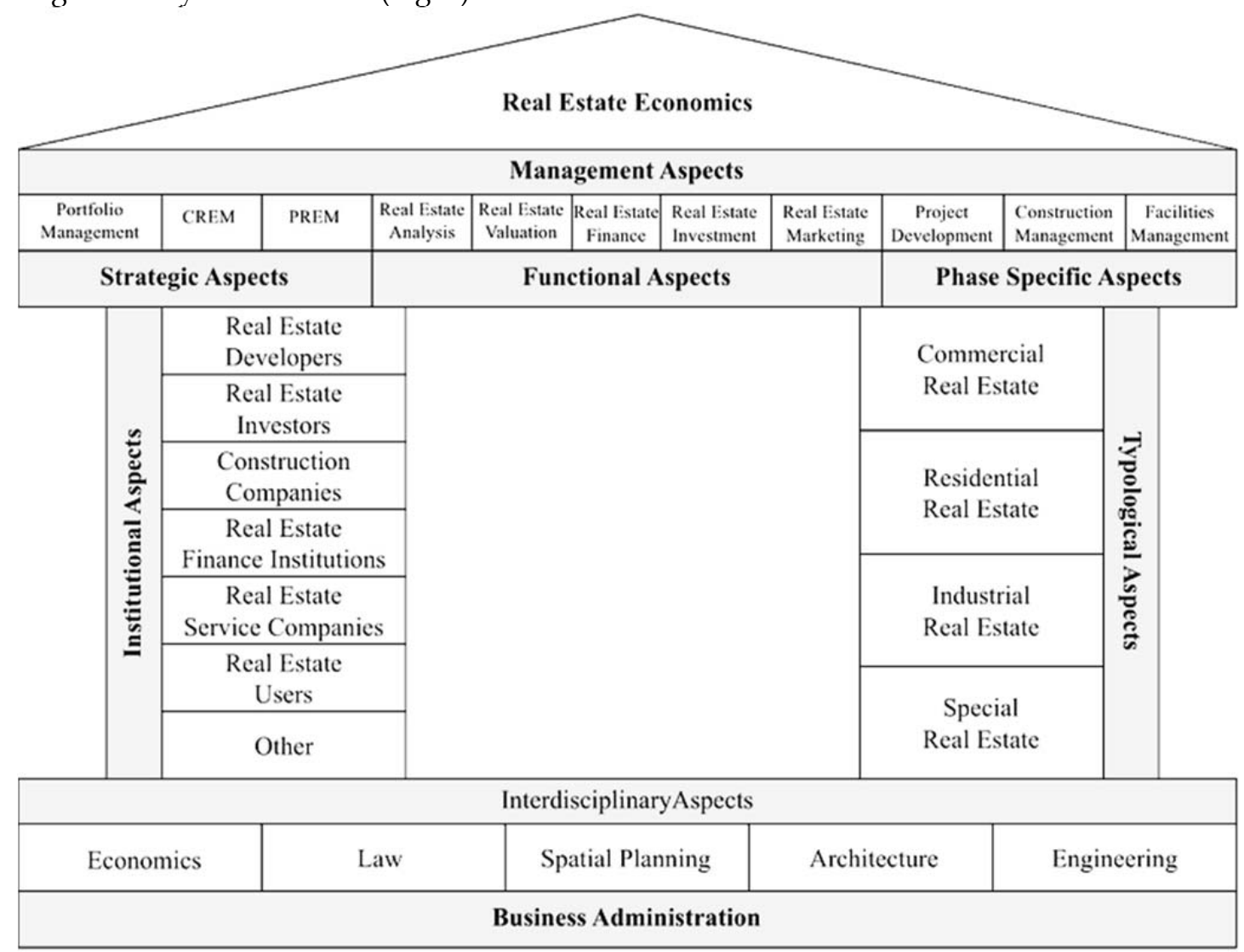

Fig. 1. „House of Real Estate Economics”. Source: SCHULTE (2003). 
Both in Polish as well as foreign literature on the subject, a lot of attention is given to the widelyunderstood processes of economic and social changes, which comprise the background and macrosurroundings of investment decisions connected with locating capital in various projects connected with the real estate market (e.g. KRÜGER 2016; BOGLE 2009; MANSFIELD 1980; HEINZE, NAEGELE 2009; UBS Global 2015; Stiglitz 2010; TiROle, Rochet, DEWATRIPONT 2010; SHILlER 2016; GRAHAM, BUFFETT, ZWEIG 2003; GRAHAM 2009; BALCEROWICZ 2012; JONES 2015; DEMBINSKI 2014). Similarly, the real estate market is the subject of many questions, studies and publications, both in foreign as well as Polish topic-related literature (e.g. LUMBY 1998; VOICU, SEILER 2013; KUCHARSKA-STASIAK 2008; KUCHARSKASTASIAK 2016; BROWN 2015; DONNER 2000; GLINDRO et. al. 2010; BRYX 2006; FORYŚ 2011; PAGLIARI 2017; FIGURSKA, WIŚNIEWSKI 2016). A review of the scientific output on the topic of the evolution of knowledge regarding real estate was presented, among others, by W. Breuer and C. Nadler, indicating works of Mertzke from the beginning of the past century, then later, onto publications of Wendt and Weimer from the $50 \mathrm{~s}$ and 60 s of the $20^{\text {th }}$ century, up to more current works from the 90 s of the $20^{\text {th }}$ century in Diaz as well as Grissom and Liu, emphasizing the ecological aspects of the market. Completing this synthetic - due to the framework of the present work - review of the evolution of directions of research and viewpoints on the topic of the development of the real estate market with newer selected foreign and Polish publications, it is especially worth drawing attention to those by the nestor of the Polish real estate market - professor Leszek Kałkowski, as well as professors Ewa Kucharska-Stasiak and Mark Bryx (Tab. 1).

Contribution of knowledge on the real estate market in chronological order

Table 1

\begin{tabular}{|c|c|c|}
\hline Author & Year & Approach \\
\hline Mertzke & 1927 & Land Economics Approach \\
\hline Hoyt & 1939 & $\begin{array}{l}\text { A scientific work on the topic of business cycles on the real } \\
\text { estate market, e.g. on the land market in Chicago, first appears } \\
\text { and is expanded on in later years ( } 80 \text { s and } 90 \text { s of the } 20^{\text {th }} \\
\text { century) }\end{array}$ \\
\hline Wendt & 1949 & $\begin{array}{l}\text { Real Estate Economics Approach, sub-disciplines: brokerage, } \\
\text { finance, appraisal, management and development }\end{array}$ \\
\hline Weimer & 1959 & $\begin{array}{l}\text { Business Administration Approach: real estate management to } \\
\text { maximize shareholder value }\end{array}$ \\
\hline Ratcliff & 1966 & $\begin{array}{l}\text { Revival of Land Economics Approach, stressing the importance of } \\
\text { city planning, regional science economics and urban land } \\
\text { economics as sub-disciplines }\end{array}$ \\
\hline Rowlands & 1967 & $\begin{array}{l}\text { Unification of approaches by combining micro-decision } \\
\text { processes of the firm and macro-complexity of the } \\
\text { environment; preparation of Multidisciplinary Approach }\end{array}$ \\
\hline Graaskamp & $\begin{array}{l}1976 \\
\text { and } \\
1981\end{array}$ & $\begin{array}{l}\text { Multidisciplinary Approach: Real estate should not be confined to } \\
\text { one discipline but be multidisciplinary } \\
\text { The Fundamentals of Real Estate Development }\end{array}$ \\
\hline $\begin{array}{l}\text { Dasso and } \\
\text { Woodward }\end{array}$ & 1980 & $\begin{array}{l}\text { Financial Management Approach (in the line of Weimer): } \\
\text { Extension of the financial management framework to real } \\
\text { estate: Introduction of Corporate Real Estate Management }\end{array}$ \\
\hline $\begin{array}{l}\text { DiPasquale and } \\
\text { Wheaton }\end{array}$ & 1992 & $\begin{array}{l}\text { The Markets for Real Estate Assets and Space - FDW model - } \\
\text { comprehensive model of the real estate market accounting for } \\
\text { its external and internal relationships and dependencies }\end{array}$ \\
\hline Diaz & 1993 & $\begin{array}{l}\text { Systematization and Unification of Approaches: Economic } \\
\text { activity versus resource allocation }\end{array}$ \\
\hline Grissom and Liu & 1994 & $\begin{array}{l}\text { Integrative Philosophocal Basis for real estate discipline (in the } \\
\text { line of Graaskamp) }\end{array}$ \\
\hline Kucharska-Stasiak & since 1997 & $\begin{array}{l}\text { Real Estate and the Market (1997), Real Estate Market: Selected } \\
\text { Problems (1999), Real Estate in the Market Economy (2006), } \\
\text { Economic Dimension of Real Estate (2016) and others }\end{array}$ \\
\hline Bull, Lizieri, & 1998/ & Institutional stream in the concept of real estate market \\
\hline
\end{tabular}




\begin{tabular}{|c|c|c|}
\hline $\begin{array}{l}\text { MacGregor, Keogh, } \\
\text { D’Arcy, } \\
\text { Załęczna (2010) }\end{array}$ & 1999 & operation \\
\hline $\begin{array}{l}\text { various authors, } \\
\text { among Polish ones, } \\
\text { e.g.: Śliwiński A. } \\
\text { and B., Foryś, Bryx, } \\
\text { Gawron }\end{array}$ & $\begin{array}{l}90 \text { s of the } \\
20^{\text {th }} \text { cen. } \\
\text { and } \\
\text { currently }\end{array}$ & $\begin{array}{l}\text { - Concept of marketing places on the grounds of spatial } \\
\text { planning, city placement } \\
\text { - Modern models of real estate management, including the FM } \\
\text { model, marketing management and network models } \\
\text { - Using IT techniques in various areas of the real estate market }\end{array}$ \\
\hline Kałkowski & $\begin{array}{l}2003 \text { and } \\
\text { later }\end{array}$ & $\begin{array}{l}\text { Polish Real Estate Market: Opening Balance upon Poland Entering } \\
\text { the European Union (2007) } \\
\text { Real Estate Market in Poland (2003) }\end{array}$ \\
\hline Bryx & 2006 & Systemic Approach to Real Estate Market \\
\hline $\begin{array}{l}\text { Krugman, Myers, } \\
\text { Stiglitz, Roubini, } \\
\text { Mihm, Lewis, } \\
\text { Shiller, Marcinek, } \\
\text { Kucharska-Stasiak, } \\
\text { Główka, } \\
\text { Konowalczuk, } \\
\text { Jajuga, Wiśniewski }\end{array}$ & $\begin{array}{l}2007 \text { and } \\
\text { later }\end{array}$ & $\begin{array}{l}\text { - globalization, migration of capital, } \\
\text { - financial crises and the Real Estate Market, } \\
\text { - bubbles on the real estate market, } \\
\text { - cycles on the real estate market, } \\
\text { - financial (im)balance in the global economy, } \\
\text { - risk on the real estate market, } \\
\text { - real estate valuation models }\end{array}$ \\
\hline $\begin{array}{l}\text { e.g. Bryx, Belniak, } \\
\text { Siemińska, } \\
\text { Szelągowska, } \\
\text { Lorens, Henzel }\end{array}$ & $\begin{array}{l}\text { After year } \\
2000 \text { and } \\
\text { currently }\end{array}$ & $\begin{array}{l}\text { - sustainable development, including ecological construction, } \\
\text { the concept of ethics and social responsibility on the real } \\
\text { estate market, including the GRETI and RESPECT INDEX } \\
\text { (RI) } \\
\text { - revitalization } \\
\text { - city management, urban planning, } \\
\text { - interdisciplinary, including behavioral approach to the } \\
\text { functioning of various groups of real estate market } \\
\text { stakeholders }\end{array}$ \\
\hline
\end{tabular}

Source: BREUER and NADLER (2012).

The need for market transparency, which became observable especially following subsequent financial crises and price bubbles on the real estate market, the migration of capital in the environment of global connections, widespread growth of uncertainty and risk, increasing ecological and ethical awareness, as well as increasingly more advanced and more and more widely implemented IT techniques are the main challenges and thus determinants of the development of the modern real estate market. It is worth noting that some the indicated current directions of market development in the world are confirmed by a further part of the present work.

\section{Research data and methods}

The work analyzes and makes use of rich current information databases of the most renowned centers and companies monitoring the world and local real estate markets. Many reports are of a sectoral or problematic character, but due to the scope and nature of the present paper, attention was focused on the most important and most recognizable phenomena characterizing the intensity and directions of investing in assets on the real estate market throughout the world.

The work uses the method of comparative analysis and the expert method for recognizing the described trends and phenomena. The results of the carried out studies are of a practical and scientific nature, as they can contribute to indicating the main directions of searching for and developing segments and areas of the real estate market which are attractive for investors. Market participants must constantly adapt their investment strategies to the changing market situation, thus the necessity for systematic monitoring and studying of conditions as well as the level of investment activity to be carried out. Depending on the information needs and the scale of this activity, in practice, these studies often require more in-depth analyses for understanding, not only in the statistic layer, the complex and multithreaded determinants and relationships occurring on both the home market of a given investor as well as on the host markets (KUZEL 2017). 


\section{Geopolitical determinants of investment activity on the real estate market}

In addition to the earlier described events of 2016 of fundamental importance (Brexit and USA presidential election) influencing the operation and decisions of many global and national market participants, it is also worth pointing out the following "milestone" events which will take place in 2017 and 2018 (Tab. 2). All of these determinants, even though they often have a political dimension, generate new types and levels of risk, significantly influencing, e.g. the flows of capital as well as investment decisions made in many world economies. The consequences of these decisions, however difficult to predict today, will - as has been emphasized by many experts - continue to be felt for a long time in various fields and spheres of our activity, also including the real estate market (What next for European ... 2017; Megatrendes... 2016; Emerging Trends in Real Estate. New market... 2017; Emerging Trends in Real Estate. Beyond ... 2016; UBS GLOBAL 2015; The Global Risks Report; 2016).

Key areas of risk on the international arena in the years 2017-2018

Table 2

USA - January 2017, Donald Trump becomes president, fears
regarding the directions, priorities and types of economic
policy: forecast of economic protectionism

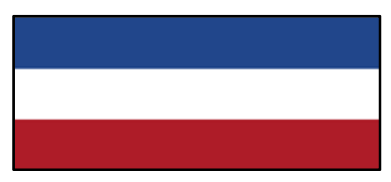

Holland - March 2017 parliamentary elections

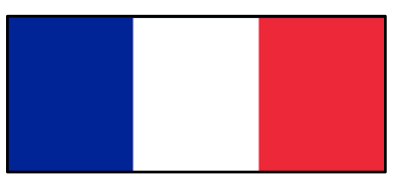

France - April - May 2017 - presidential elections

\begin{tabular}{ll}
\hline Germany - August - September 2017 parliamentary elections \\
\hline${ }_{* \star *}^{*}$
\end{tabular}

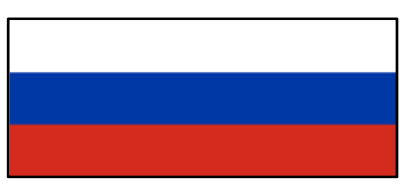

Russia - March 2018 presidential elections

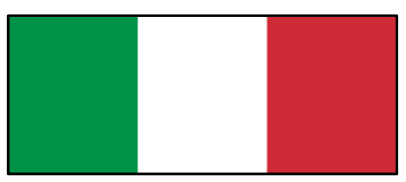

Italy - May 2018 - parliamentary elections 
Greece - October 2018 - parliamentary elections are to take place no later than this data

Source: CUSHMEN and WAKEFIELD (2017, p. 3).

\section{World real estate market - global assessment}

In terms of the value of transactions made on the worldwide real estate market - according to experts Cushman \& Wakefield - the undisputed leader for years has been the American market, the size of which in 2016 was estimated to be at the level of nearly 540 billion USD. The second in the international arena is the Asia Pacific market with a value of investments on the real estate market at the level of 448 billion USD, whilst the third - that of Europe, the Middle East and Africa, at the level of 347 billion USD (Fig. 2).

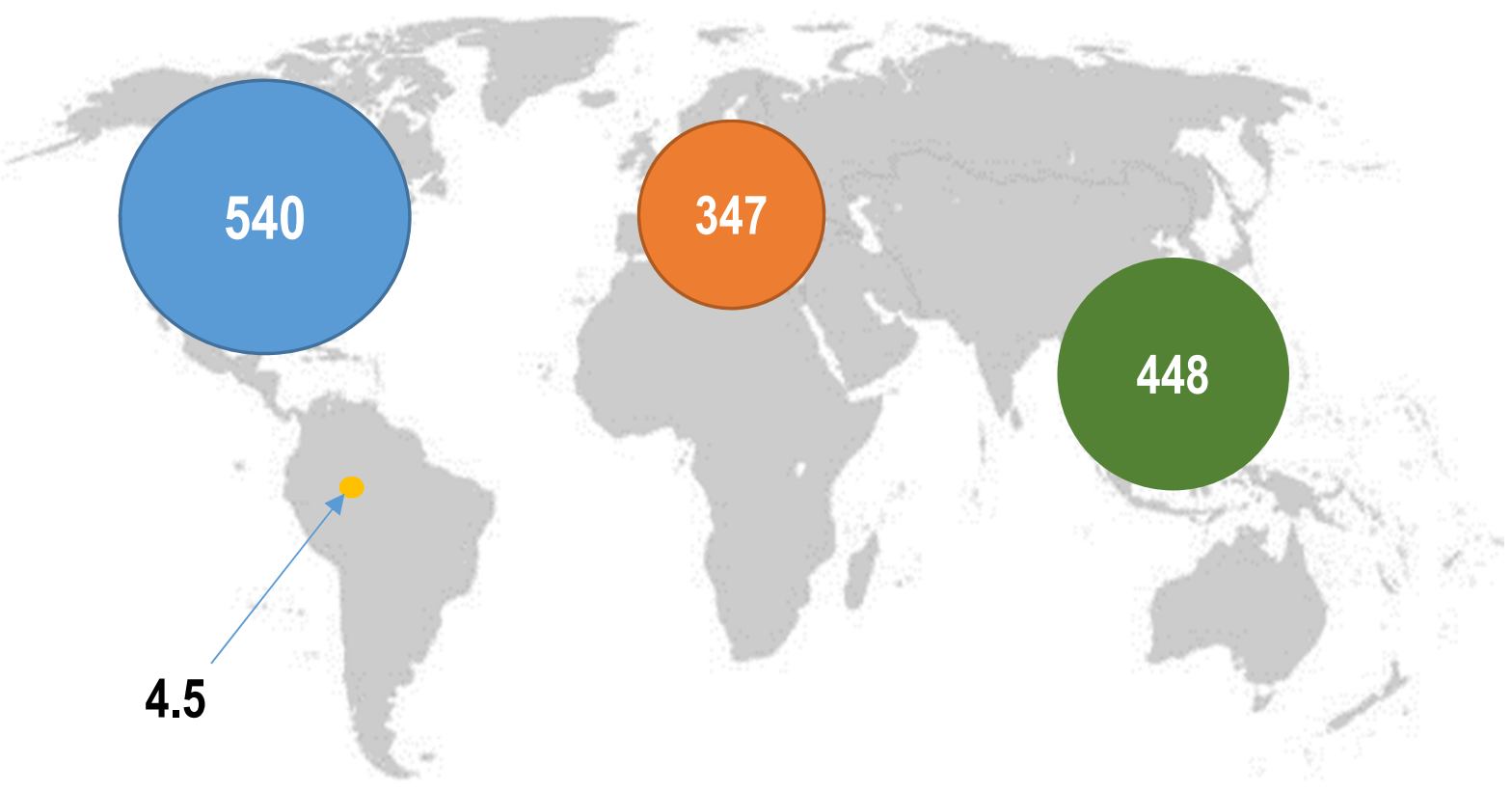

Fig. 2. Value of transactions on the world real estate market in 2016 (billion USD). Source:

CUSHMAN and WAKEFIELD (2016).

It is worth noting at this point that the market of Europe, the Middle East and Africa has moved into first place in terms of the growth dynamics of the value of transactions on the real estate market planned for the year 2016 as compared to 2015, at the level of $8.4 \%$; in second is the American market with an increase at the level of $3.5 \%$, while in third - the Asia Pacific market with dynamics assessed at $1.5 \%$. This last, relatively low level, is attributed mainly to the significant deceleration in the growth rate of the Chinese economy.

After a financial crisis in 2008 which carried with it severe consequences (KRUGMAN 2009; STIGLITZ 2010; ROUBINI, MIHM 2010; LEWIS 2010), the real estate markets are slowly, at different rates depending on the individual countries, rebuilding their resources and levels of profitability. However, currently, a high scale of uncertainty and lack of continuity in forecasting future scenarios on this market are emphasized due to the earlier mentioned geopolitical determinants, the accumulation of which will take place in 2017-2018. That is why much importance is placed on seeking out and improving the effectiveness of various methods of early warning, also for the needs of investment activity on the real estate market and the organically high financial exposure connected with it (Understanding the Commercial Real Estate... 2016; Megatrendes... 2016; CZERNIAK, WITKOWSKI 2016; WORETA, SANKOWSKI, SEPIELAK 2010; WIŚNIEWSKI, BRZEZICKA 2014).

Investors, looking for relatively safe directions for allocating capital, account for their potential for increase as well as the level of risk and market transparency which is connected with it. As results 
from the recent Global Real Estate Transparency Index - GRETI, which for 10 years has been annually developed by two companies, i.e. JLL and LaSalle Investment Management, in the recent years, among the 109 analyzed countries, 3/4 of them have improved the level of transparency on their national real estate markets. This level, according to GRETI methodology, is influenced by an assessment of 139 factors regarding, e.g.: key market parameters, real estate market efficiency indicators, the system of supervising entities noted on the organized markets, legal regulations as well as the quality of legislation, regulations connected with servicing various transactions concluded on the real estate market, ecology, as well as the transparency and ethics of transaction processes. Especially recently, after the disclosing of the highly publicized Panama Papers scandal at the beginning of 2016, the social awareness and pressure for the substantial improvement of transparency on real estate markets, including procedures for the disclosure of ownership and absolute combatting of money laundering, has been increasing. Such pressure and expectations have been increasing along with the global spread of modern techniques of transmitting and processing data, as well as preferences connected with sustainable development (Global Real Estate Transparency Index, 2016).

The ten most model-like markets in terms of transparency are those of: Great Britain, Australia, Canada, The United States, France, New Zealand, Holland and Finland (Tab. 3). What is important is that the 10 mentioned countries attract $75 \%$ of worldwide investments in the segment of real estate, while the following 20 countries, qualified in the group of transparent markets, attract $20 \%$ of investments in real estate worldwide.

Global Real Estate Market Transparency Index (GRETI) 2016

Table 3

\begin{tabular}{|c|c|c|}
\hline GRETI Level & Position in GRETI Index & Country \\
\hline \multirow{10}{*}{ 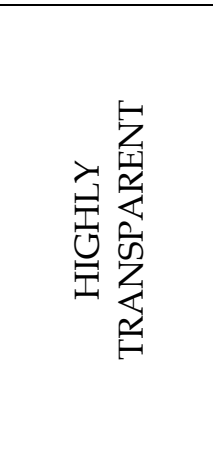 } & 1. & GREAT BRITAIN \\
\hline & 2. & AUSTRALIA \\
\hline & 3. & CANADA \\
\hline & 4. & UNITED STATES \\
\hline & 5. & FRANCE \\
\hline & 6. & NEW ZEALAND \\
\hline & 7. & HOLAND \\
\hline & 8. & IRLAND \\
\hline & 9. & GEMANY \\
\hline & 10. & FINLAND \\
\hline \multirow{10}{*}{ 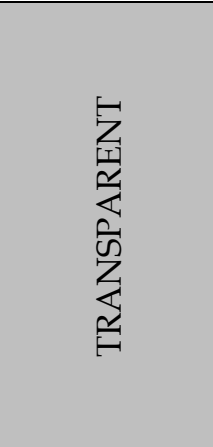 } & 11. & SINGAPORE \\
\hline & 12. & SWEDEN \\
\hline & 13. & POLAND \\
\hline & 14. & SWITZERLAND \\
\hline & 15. & HONG KONG \\
\hline & 16. & BELGIUM \\
\hline & 17. & DENMARK \\
\hline & 18. & NORWY \\
\hline & 19. & JAPN \\
\hline & 20. & CZECH REPUBLIC \\
\hline
\end{tabular}

Source: www.jll.com/Transparency (2016).

This, thus, signifies the importance and strength of influence that business transparency has on the taken investment decisions and thus, also decisions regarding the inflow of capital to given markets (Global Real Estate Transparency Index 2016). The synthetic indicator of transparency is a tool more and more frequently applied by investors when creating investment strategies and choosing directions of allocating resources to individual countries, as well as a tool for managing risk, thanks to the possibility of comparing data for many alternative geographical locations. The beneficiaries of information on the level of transparency of operating on the real estate market are also governments and public authority bodies responsible for decisions and actions on behalf of improving the transparency of the economy, and also local societies and corporations for whom it is easier to 
compare the possibilities and conditions of operation of planned business projects and influence the improvement of their effectiveness as well as quality of managing real estate.

\section{Main sectors of the real estate markets accounting for the phase of the business cycle}

When analyzing the changes taking place on the world real estate market in greater detail, it is first worth drawing attention to its main segments, and second - to their development in terms of the phase of the business cycle. That is why, in this part of the work, the three main segments of real estate, i.e. retail, office and warehouse, have been synthetically presented accounting for the phases of their development, using the so-called business cycle clock, the concept of which was first presented by Floris van Ruth, Barry Schouten and Roberto Wekker (RUTH, SCHOUTEN, WEKKER 2005). The location of the given market on the face of the business cycle clock is an important piece of information for each investor contemplating the various variants of business strategies of entering or existing the given market or project, especially that dynamic technological and environmental changes which, in practice, often require fast realization are simultaneously taking place.

The market of retail space is experiencing a difficult time of many challenges throughout the world - in certain regions - falls, the closing of chain stores, difficulties with renting out space in shopping centres or the tightening of rental conditions, which is the result of at least a few important factors. This especially regards (UBS GLOBAL 2015; Understanding the Commercial Real Estate... 2016; European Real SnapShot! 2016; REAL ESTATE 2020; European Retail Market 2016-2017):

- Strong growth of consumer preferences towards e-commerce type trade and, in connection with this, the model of deliveries, so-called final-mile delivery models, which carries over to a decreased need for traditional retail space,

- The domination of services provided by the gastro-entertainment sector in shopping centers and galleries at the expense of sales results of other sectors,

- Problems with finding strategic tenants (so-called anchor tenants) in shopping centers which, in turn, makes the profitability of maintaining an entire complex questionable.

The conditions encourage investors all over the world to focus on the best markets and addresses, with the highest sales potential, which are capable of attracting high numbers of clients for the longest possible time. In order to fulfill this, traditional economic analyses of economic efficiency are often supported by more in-depth studies on the types of generations of people, their preferences and behaviors, shopping styles, sociological changes, etc.

The current scheme of retail real estate markets for the largest agglomerations in the world accounting for the phase of their business development has been presented in Figure 3. It shows that the biggest American agglomerations (Washington, Los Angeles, Houston, San Francisco, New York, Boston) are in a growth phase, while European and Asian cities - depending on the situation - are noting both growth potential (e.g. Paris, Tokyo, Shanghai or Madrid and London) as well as decline (Dubai, Hong Kong or Singapore and Moscow).

Strongly connected with the mentioned retail real estate market is the development of the market of warehouses for which a further intensive increase in demand is expected, especially for large-scale warehouses often built in the neighbourhood of large cities, which require vast spaces and are often constructed in the build-to-suit formula. This is the effect of dynamically developing, earlier mentioned , e-commerce services and delivery models, so-called final-mile delivery models (Last Mile Logistic), which are the reason behind the ongoing increased demand of tenants and the absorption of many, especially newly-built spaces, which, in turn, leads to lowering the level of vacant buildings in certain locations to record lows. Nevertheless, as pointed out by experts, the European market will limit its growth rate at an estimated relatively low level, i.e. $6 \%$, of abandoned spaces, which carries over to the lack of a tendency for increasing rents. This is, among others, the effect of competitive rents available on the build-to-suit market (Real Estate Markets Maintain Late-Cycle Growth..., 2016, European Real SnapShot!, 2016). On the other hand, continued dynamic development with growth perspective is predicted for the American market, as confirmed by the location of the largest agglomerations in the United States of America on the face of the business cycle clock, e.g. - Atlanta, New York, Los Angeles, Philadelphia, Dallas, San Francisco, etc. On the Canadian market of warehouse spaces, record low levels of abandoned spaces are being noted (2.9\%). The Asian market, on the other hand, is more varied seeing as how some agglomerations, such as Singapore, are noting significant downward trends, and others, e.g. Beijing, Shanghai or Hong Kong - upward tendencies (Fig. 4). 


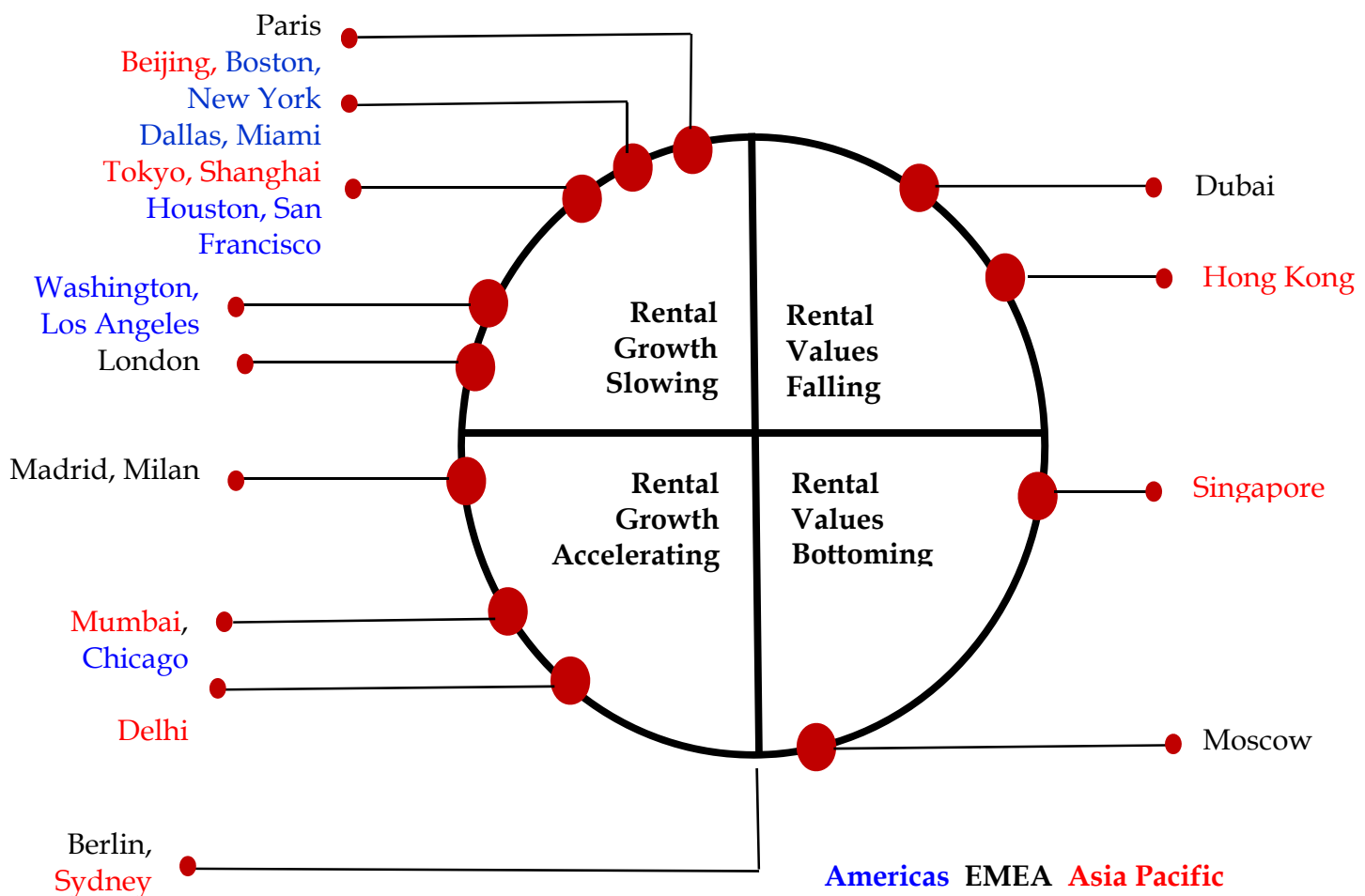

Fig. 3. Prime Retail - Rental Clock, Q3 2016. Source: JLL (2016, p. 31).

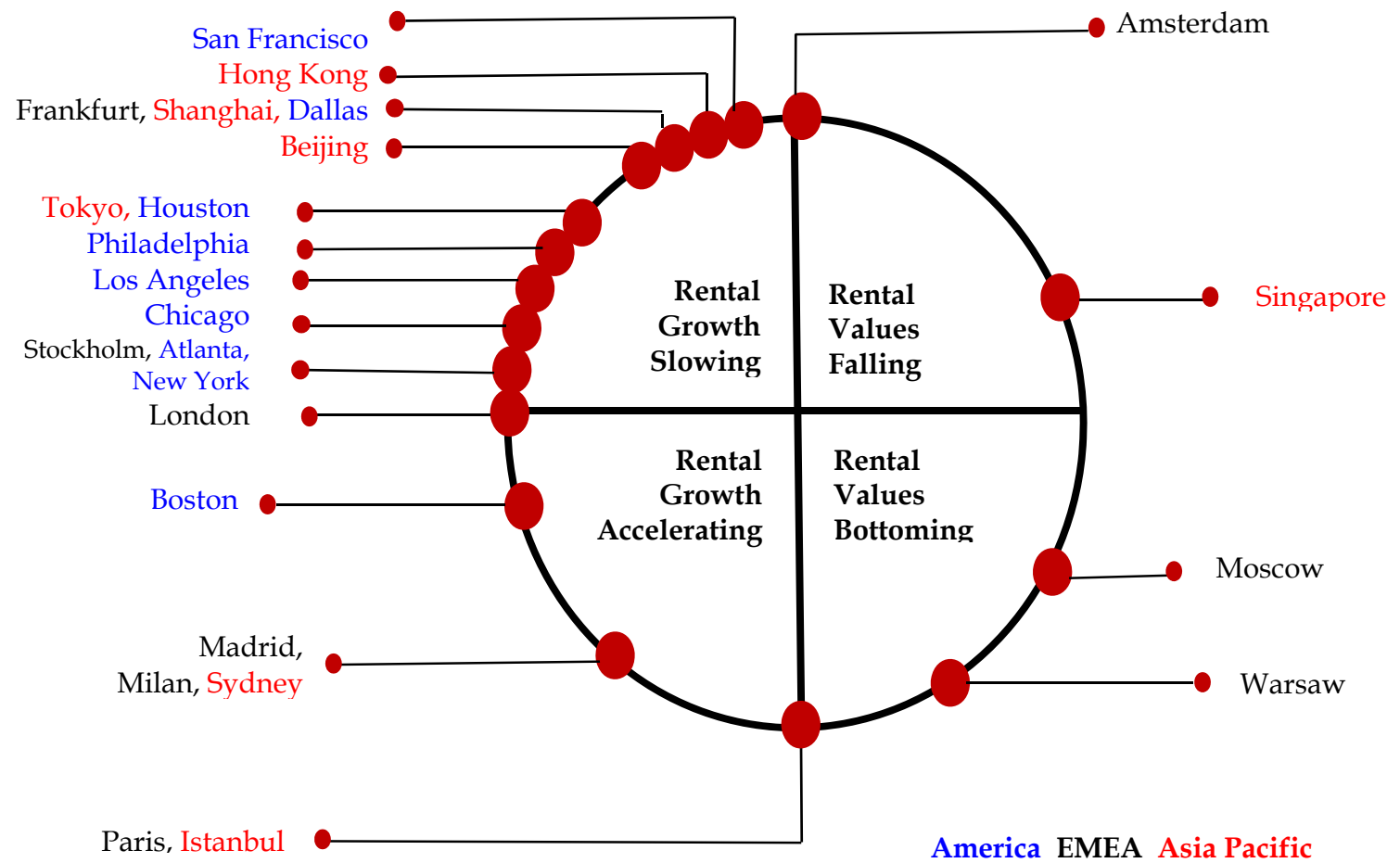

Fig. 4. Prime Industrial - Rental Clock, Q3 2016. Source: JLL (2016, p. 31).

On the market of office space, similarly to retail space, one of the most important features influencing the attractiveness and market value of a given project is the location which, under conditions of limited spatial possibilities, especially in the largest agglomerations, leads to increased competition and taking what are often risky investment decisions. Moreover, according to the newest standards and urban-zoning trends, especially newly created spaces must fulfil extremely individualized and demanding expectations and needs of future users, which influences their 
competitive advantage and thus, business profitability (JUDD R., 2016, Real Estate 2020). On the other hand, however, changes in the possibilities of the place and means of carrying out professional activities, thanks to systems enabling communication and working off-site make it so that office services do not always require spaces specifically dedicated to them. A large portion of American agglomerations offering office real estate is in the growth phase, which is connected with good results in employment levels and growth in many sectors of the economy as well as European cities (with the exception of London). The Asian market of office real estate in large agglomerations (Hong Kong or Singapore) on the contrary, is noting clear downward trends due to the deceleration of the Chinese and Indian economies (Fig. 5).

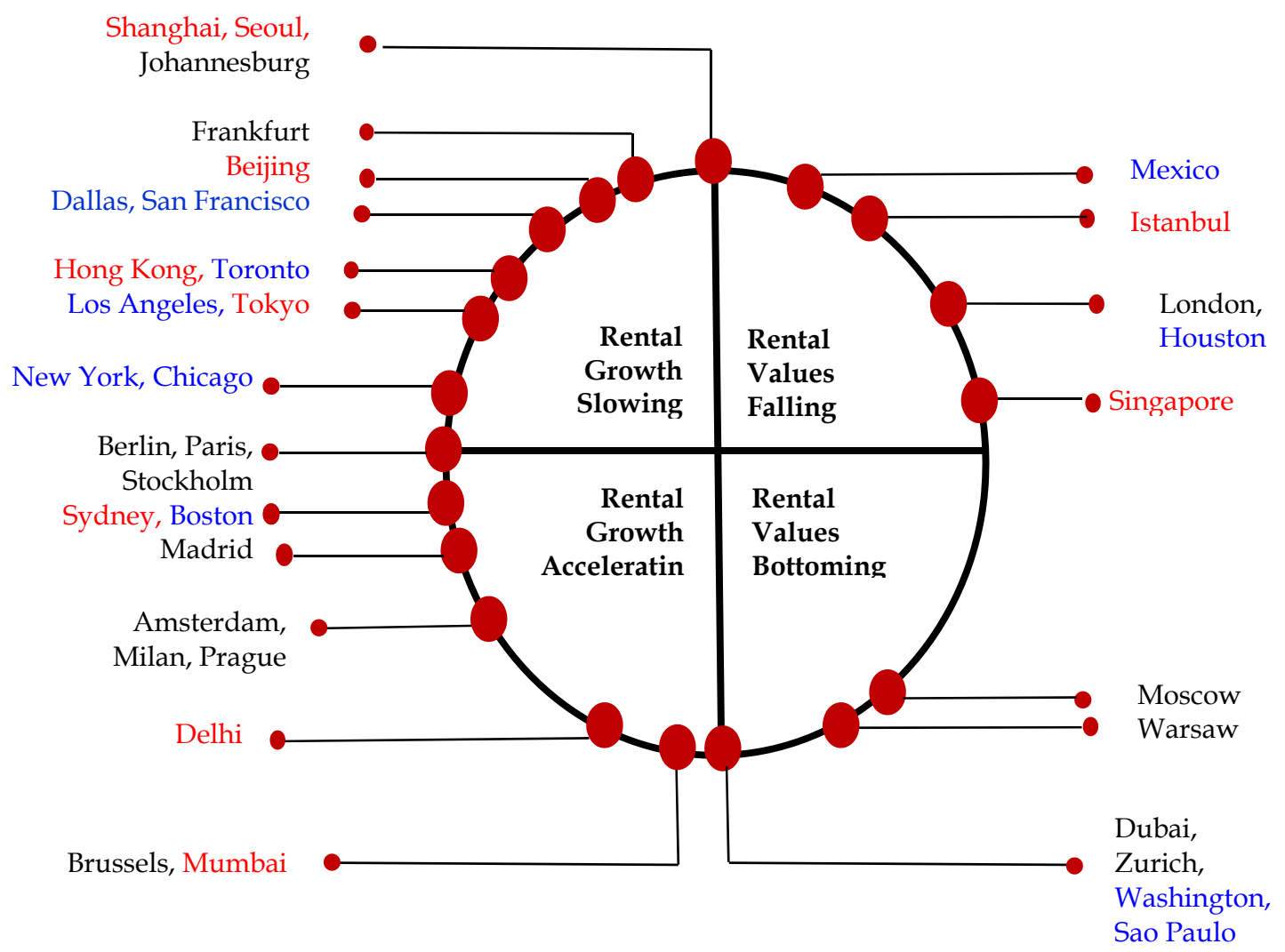

Fig. 5. Prime Offices - Rental Clock, Q3 2016. Source: JLL (2016, p. 31).

To sum up, the largest commercial real estate markets in 2016 in terms of the investment volume include: New York (especially Manhattan), London, Los Angeles, San Francisco, Paris Tokyo, Chicago, Boston, Washington, Hong Kong, Shanghai, Seattle, Sydney, Singapore and Melbourne (Global Cities, 2017, p. 5). It is worth noting at this point that the excessive concentration of services, infrastructure or places of meeting various human needs carries with it numerous risks and challenges of an urban planning, spatial, communication, social, ecological, demographic, and technical nature, and many more. Moreover, it contributes to the polarization of investment intensity in a global, regional as well as local dimension. In order to illustrate this phenomenon, it is worth reporting here that 300 of the largest agglomerations in the world carried out nearly $72 \%$ of investments worldwide on the real estate market (Globalisation and Competition... 2015; Global300... 2015; Global Cities 2017; Eco-innovations ... 2015; Innowacje w zarzadzaniu... 2014).

\section{Some remarks regarding the influence of Brexit on the real estate market}

Against the assumed deliberations, the earlier-mentioned problem of Brexit should at least be mentioned. It is difficult to unequivocally predict the influence of Great Britain exiting the European Union on the changes in the real estate market on a worldwide, European Union or national scale. Not knowing the legal, fiscal, and financial conditions, as well as the rate of this process, we can merely assume certain scenarios of investor behaviours, especially considering that, as of now, emotional bases prevail (SAMPSON 2016; BREXIT 2016). According to JLL experts, a high level of uncertainty leads 
to an atmosphere of expectance and careful observation of the situation, and thus putting off the decision of possibly changing the location of the carried out business until becoming more familiar with new rules and conditions of operation. At a 5\% level of abandoned office space in London and $3 \%$ in the West End district, it is difficult to predict the radical degradation of these parameters. At the same time, it has been unequivocally emphasized that the leaving of London City by world financial powers would lead to immense losses for the entire British economy, at the same time pointing to the potential beneficiaries, who would be able to assume at least some of the foreign banks, e.g.: Frankfurt, Berlin, Paris, Luxemburg or Dublin (Real Estate Markets Maintain Late-Cycle Growth 2016; Brexit $\mathcal{E}$ The European... 2016; SAPIR, SCHOENMAKER, VERON 2017; BATSAIKHAN, KALCIK, SCHOENMAKER 2017). An example of such activities is, among others, the meeting of representatives of the German Federal Financial Supervisory Authority (Bundesanstalt für Finanzdienstleistungsaufsicht - BaFin) in Frankfurt at the end of January 2017, as with nearly 50 representatives of foreign banks in order to encourage them to transfer their operations over to Germany (Brexit: BaFin informiert Auslandsbanken, 2017). The most important implications of Great Britain leaving the EU, in turn, include strengthening the position of London on the world real estate map due to the unique values of the British capital as the center of trade and business. In a short-term perspective, however, the possibility of suffering painful losses connected with the significant decrease of the inflow of direct foreign investments by approximately 22\% (DHINGRA et. al. 2016), aggravated by the outflow of capital and workplaces, and thus decreased demand on the housing market and losses resulting from the weakening of the British currency, are emphasized (Brexit $\mathcal{E}$ The European... 2016, p. 16; SMITH 2017; EU Referendum... 2016). In the context of these reflections, it is worth emphasizing that the results of Brexit have to be looked into not only in terms of London, which is an unquestionable benchmark on the global market, but also in view of local, more peripheral markets, which may be much more severely affected by exiting the structure of the EU.

\section{Conclusions}

A recognizable feature of the modern economy are, on one hand, the dynamic and multi-directional changes, and on the other hand, often a discontinuity of the phenomena taking place, which leads to increased risk and uncertainty of operation of very many various market participants, or even difficulties in predicting the future. This problem is particularly acute when it concerns the activity of investors on the real estate market, as, firstly, it requires them to make decisions well in advance, and secondly, necessitates engaging significant financial resources. That is why, in practice, such decisions are usually preceded by various research and in-depth analyses aimed at decreasing at least part of the risks accompanying investment processes.

The work signalizes the most important current geopolitical as well as economic phenomena and determinants which accompany the changes taking place on the world real estate market. On the one hand, the high concentration and competitiveness of investment activity on selected markets and, on the other, the changing preferences of consumers as well as ecological awareness and requirements regarding the transparency of operation necessitate the search for and adaptation of action strategies of many investors. At the same time, however, the real estate market is often affected by external political, economic or environmental factors, often exerting a very strong influence, without accounting for which it is impossible to run a successful business.

\section{References}

AKerlof G.A., SHILler J. R., 2015, Phishing for Phools: The Economics of Manipulation and Deception, Princeton University Press, Princeton and New Jersey.

ANOP S., 2010, Determinants of Foreign Direct Investments in Real Estate in European countries? Panel Data Analysis, ResearchGate.

Atlas Outlook 2016, Cushman \& Wakefield.

BALCEROWICZ L. 2012, Odkrywając wolność. Przeciw zniewoleniu umysłów (Discovering Freedom. Against the Slavery of Minds) [in Polish], Wydawnictwo ZYSK i S-KA, Poznań.

BATSAIKHAN U., KALCIK R., SCHOENMAKER D., 2017, Brexit and the European Financial system: mapping markets, players and jobs, BRUEGEL, Brussels. 
BELNIAK S., 2009, Rewitalizacja nieruchomości w procesie odnowy miast (Revitalization of Real Estate in the Urban Renewal Process) [in Polish], Wydawnictwo Uniwersyteu Ekonomicznego w Krakowie, Kraków.

Bogle J. C., 2009, Enough: True Measures of Money, Business, and Life, John Wiley \& Sons, New Jersey.

BOLEAT M., COLES A., 2012, The mortgage market. Routledge, New York.

BOROWSKA M., DOMAŃSKA J., 2016, Wspótczesny rynek nieruchomości jako obszar dociekań naukowych w świetle literatury (Current Real Estate Market as an Area of Scientific Investigation in Light of Literature) [in Polish], Zeszyty Naukowe Uniwersytetu Ekonomicznego w Katowicach No. 270.

BReUer W., NADleR C., 2012, Real Estate and Real Estate Finance as a Research Field - An International Overview, Journal of Business Economics, Real Estate Finance, Springer Science \& Business Media, Special Issue 1.

Brexit \& The European Property Investment Market, 2016, Cushman \& Wakefield,

BREXIT, 2016, Policy Analysis from the Centre for Economic Performance. Centre for Economic Performance.

Brexit: BaFin informiert Auslandsbanken, BaFin 2017, https:/ / www.bafin.de.

Brown P. H., 2015, How Real Estate Developers Think. Design, Profits, and Community, University of Pennsylvania Press.

BRYX M. (ed.), 2014, Innowacje w zarzadzaniu miastami w Polsce (Innovations in City Management in Poland) [in Polish], Oficyna Wydawnicza SGH, Warszawa.

BryX M., 2006, Rynek nieruchomości. System i funkcjonowanie (Real Estate Market. System and Functioning) [in Polish], POLTEXT, Warszawa.

BRZEZICKA J., WISNIEWSKI R., 2014a, Identifying Selected Behavioral Determinants of Risk and Uncertainty on the Real Estate Market, Real Estate Management and Valuation, Vol. 22, No. 2, pp. 30-40. DOI: 10.2478/remav-2014-0015.

BRZEZICKA J., WIŚNIEWSKI R., 2014b, Price Bubble in the Real Estate Market - Behavioral Aspects, Real Estate Management and Valuation, Vol. 22, No. 1, pp. 80-93. DOI: 10.2478/remav-2014-0010.

CZERNIAK A., WITKOWSKI B., 2016, Model wczesnego ostrzegania przed bańkami cenowymi na rynku mieszkaniowym (Model of Early Warning about Price Bubbles on the Real Estate Market) [in Polish], NBP, Warszawa.

DEMBINSKI P., 2014, Kryzys ekonomiczny i kryzys wartości (Economic Crisis and Value Crisis) [in Polish], Wydawnictwo M, Kraków.

DHingRa S., OtTAVIANO G., SAMPSON T., REENEN J., 2016, The Impact of Brexit on Foreign Investment in the UK, Centre for Economic Performance, London School of Economics and Politital Science, London.

Dipasquale D., Wheaton W.C., 1992, The Markets for Real Estate Assets and Space: A Conceptual Framework, Journal of the American real Estate and Urban Economocs Association, Vol. 20, pp. 181-197.

DONNER Ch., 2000, Housing Policies in the European Union. Theory and Practice. Austrian Federal Ministry of Economic, Affaires and Labour. Vienna, December.

Emerging Trends in Real Estate. Beyond the capital. Europe, 2016, PWC.

Emerging Trends in Real Estate. New market realities. Europe, 2017, PWC,

EU Referendum: Making Sense of Brexit - update, 2016, JLL.

European Real SnapShot!, 2016, KPMG.

European Retail Market 2016-2017, SAVILLS.

FIGURSKA M., WiŚNIEWSKI R., 2016, Fundamental Analysis - Possiblity of Application on the Real Estate Market, Real Estate Management and Valuation. Vol. 24, Issue 4, pp. 35-46. DOI:10.1515/remav2016-0028.

FORYŚ I., 2011, Społeczno-gospodarcze determinanty rozwoju rynku mieszkaniowego w Polsce (Socio-economic Determinants of Housing Market Development in Poland) [in Polish], Uniwersytet Szczecinski, Szczecin.

GAWRON H., 2006, Opłacalność inwestowania na rynku nieruchomości (Profitability of Investing on the Real Estate Market) [in Polish], Akademia Ekonomiczna w Poznaniu.

Glindro E.T., Subhanij T., Szeto J., ZHu H., 2010, Determinants of House Prices in Nine Asia-Pacific Economies, BIS Papers No. 52. http:/ / www.bis.org/publ/bppdf/bispap52.htm.

Global Cities, 2017, Report, Knight Frank.

Global Real Estate Transparency Index, 2016, JLL. www.jll.com/Transparency 
Global300 The New Commercial Geography of Cities, 2015, JLL.

Globalisation and Competition: The New World of Cities, 2015, JLL.

GŁÓWKA G., 2012, System finansowania nieruchomości mieszkaniowych w Polsce (System of Financing Residential Real Estate in Poland) [in Polish], Oficyna Wydawnicza SGH, Warszawa.

GRAASKAMP J.A., 1981, The Fundamentals of Real Estate Development, ULI-the Urban Land Institute.

GRAHAM B., 2013, The intelligent investor : a book of practical counsel, Harper Collins, New York.

GRAHAM B., BUfFETT W. E., ZWEIG J., 2003, The Intelligent Investor: The Definitive Book on Value Investing, Harper Collins, New York.

Heinze R.G., NAEGele G., 2009, "Silver Economy" in Germany - More Than Only the "Economic Factor: Old Age"!, Journal on Social \& Psychological Gerontology, No. 2.

HENZEL H. (ed.), 2009, Strategie inwestowania na rynku nieruchomości (Strategies of Investing on the Real Estate Market) [in Polish], Wydawnictwo Akademii Ekonomicznej im. K. Adamieckiego, Katowice.

JAJUGA K., JAJUGA T., 2012, Inwestycje : instrumenty finansowe, aktywa niefinansowe, ryzyko finansowe, inżynieria finansowa (Investments: Financial Instruments, Non-financial Assets, Financial Risk, Financial Engineering) [in Polish], Wydawnictwo Naukowe PWN, Warszawa.

JONES E.M., 2015, Jałowy pieniadz (Sterile Money) [in Polish], Vol. I, II, III, Wydawnictwo WEKTORY, Wrocław.

JuDD R., 2016, Modern Office Standards, CBRE.

KAŁKOWSKI L. (ed.), 2003, Rynek nieruchomości w Polsce (Real Estate Market in Poland) [in Polish], TWIGGER, Warszawa.

KAŁKOWSKI L., 2007, Polski rynek nieruchomości : bilans otwarcia po wejściu Polski do Unii Europejskiej (Polish Real Estate Market: Opening Balance upon Poland Joining the European Union) [in Polish], Instytut Rozwoju Miast, Kraków.

KONOWALCZUK J., 2014, Wycena nieruchomości do celów kredytowych (Valuation of Real Estate for Mortgage Purposes) [in Polish], POLTEXT, Warszawa.

KRÜGER C., 2016, Diskurse des Alter(n)s. Öffentliches Sprechen über Alter in der Bundesrepublik Deutschland (Discourses of Age(ing): Public Speaking about Age in the Federal Republic of Germany) [in German], DE GRUYTER MOUTON.

KRUGMAN P., 2009, The Return of Depression Economics and the Crisis of 2008, W.W. Norton, New York.

KUCHARSKA-STASIAK E. (ed.), 1999, Rynek nieruchomości: wybrane problemy (The Real Estae Market: Selected Problems) [in Polish], Wydawnictwo Uniwersytetu Łódzkiego, Łódź.

KUCHARSKA-STASIAK E., 1997, Nieruchomość a rynek (Real Estate and the Market) [in Polish], Wydawnictwo Naukowe PWN, Warszawa.

KUCHARSKA-STASIAK E., 2006, Nieruchomość w gospodarce rynkowej (Real Estate in the Market Economy) [in Polish], Wydawnictwo Naukowe PWN, Warszawa.

KUCHARSKA-STASIAK E. (ed.), 2008, Cykle rynku nieruchomości a sektor bankowy (Real Estate Market Cycles and the Banking Sector) [in Polish], Fundacja na Rzecz Kredytu Hipotecznego, Warszawa.

KuCHARSKA-STASIAK E., 2016, Ekonomiczny wymiar nieruchomości (Econoic Dimension of Real Estate) [in Polish], PWN, Warszawa.

KuZEL M., 2017, The Investment Development Path: Evidence from Poland and Other Countries of the Visegrád Grou, Journal of East-West Business, Journal of East-West Business Vol. 0, Iss. 0,0 DOI: 10.1080/10669868.2016.1180659.

LeWIS M., 2010, The Big Short: Inside the Doomsday Machine, W.W. Norton \& Company, New York, London.

LORENS P., MiRONOWICZ I., 2013, Wybrane teorie wspótczesnej urbanistyki (Selected Theories of Modern-day Urban Planning), Akapit-DTP, Gdańsk.

LuMBY S., 1998, Investment Appraisal and Financial Decisions, International Thomson Business Press, London.

MANSFIELD E., 1980, Economics Principles, Problems, Decisions, WW Norton \& Company, New York.

MARCINEK K., 2001, Ryzyko projektów inwestycyjnych (Investment Project Risk) [in Polish], Wydawnictwo Uczelniane AE w Katowicach.

MCFADDEN D.L., 1994, Demographics, the Housing Market, and the Welfare of the Elderly, Studies in the Economics of Aging, National Bureau of Economic Research, http://www.nber.org/chapters/c7346 (2.02.2016).

Megatrendes in Eeuropean Real Estate, 2016, Savills. 
MYERS D., 2016, New Economic Thinking and Real Estate, Wiley-Blackwell, New Jersey.

PAgLiARI, J.L. 2017, Another Take on Real Estate's Role in Mixed-Asset Portfolio Allocations, Real Estate Economics, Vol. 45, numer 1, pp. 75-132. doi:10.1111/1540-6229.12138.

Real Estate 2020. Building the Future, PWC.

Real Estate Markets Maintain Late-Cycle Growth. Global Market Perspective, Q4 2016, JLL.

Roubini N., MinM S., 2010, Crisis Economics: a Crash Course in the Future of Finance, Penguin Press, New York.

Ruth F., SCHOUTEN B., WeKKER R., 2005, The Statistics Netherlands' Business Cycle Tracer. Methodological Aspects; Concept, Cycle Computation and Indicator Selection, Statistics Netherlands, MIC-44.

SAMPSON T., 2016, Four Principles for the UK's Brexit Trade Negotiations, Centre for Economic Performance, London School of Economics and Politital Science, London.

SAPIR A., SCHOENMAKER D., Veron N., 2017, Making the Best of Berxit for the EU27 Financial System, BRUEGEL, Brussels.

SCHULTE K.W., 2003, The Role of Investment and Finance in Real Estate Education and Research Throughout the World, Property Management, Vol. 21 Iss: 1.

SIEMIŃSKA E., 2013, Ryzyka inwestowania i finansowania na rynku nieruchomości w kontekście etyki $i$ społecznej odpowiedzialności (Risks of Investing in and Financing on the Real Estate Market in the Context of Ethics and Social Responsibility) [in Polish] Uniwersytet Mikołaja Kopernika, Torun.

Smith M.A., 2017, The 'Brexit Effect' on London Retail, http://www.jll.co.uk/united-kingdom/en$\mathrm{gb} /$ news/2923/jll-uk-centrallondon-retail-property-opinion).

STIGLITZ J. E., 2010, Freefall: America. Free Markets and the Sinking of the World Economy, W.W. Norton \& Company Ltd., New York, London.

SZELĄGOWSKA A., BRYX M., (ed.), 2015, Eco-innovations in cities, CeDeWu, Warszawa.

ŚLIWIŃSKI A., ŚLIWIŃSKI B., 2006, Facility management, C. H. Beck, Warszawa,

The Global Risks Report, 2016, World Economic Forum.

TiROle J., ROChET J.-CH., DeWATRIPONT M., 2010, Balancing the Banks: Global Lessons from the Financial Crisis, Princeton University Press, Princeton and Oxford.

UBS GLOBAL 2015. Real Estate Bubble Index.UBS.

Understanding the Commercial Real Estate Investment Ecosystem. An Early Warning System Prototype, 2016, World Economic Forum.

VOICU C., SEILER M. J., 2013, Understanding Systematic Risk in Real Estate Markets, Journal of Housing Research, 22(2).

What Next for European Property Investment ?, 2017, Cushmen \& Wakefield

WORETA R., SANKOWSKI R., SEPIELAK P., 2010, Źródła narastania akcji kredytowej w warunkach integracji walutowej, KNF, Warszawa.

ZAŁĘCZNA M., 2010, Instytucjonalne uwarunkowania rozwoju rynku nieruchomości w Polsce na tle doświadczeń państw zachodnich, Wydawnictwo Uniwersytetu Łódzkiego, Łódź. 